\title{
Widening the educational capabilities of socio-economically disadvantaged students through a model of social and cultural capital development
}

\author{
Cliona Hannon ${ }^{\mathrm{a}}$, Daniel Faas ${ }^{\mathrm{b}}$ and Katriona O’Sullivan ${ }^{\mathrm{a}, \star_{\mathbb{D}}}$ \\ ${ }^{\mathrm{a}}$ Trinity Access Programmes, Trinity College Dublin, Ireland; ${ }^{\mathrm{b}}$ Department of Sociology, \\ Trinity College Dublin, Ireland
}

\begin{abstract}
Widening participation programmes aim to increase the progression of students from low socio-economic status (SES) groups to higher education. This research proposes that the human capabilities approach is a good justice-based framework within which to consider the social and cultural capital processes that impact upon the educational capabilities of young people from low SES groups. It presents a case study which examines the developing capability set of Irish students from a representative sample of schools participating in a university-based widening participation outreach programme aimed at increasing social and cultural capital constructs. Qualitative analysis is presented from four schools; four student focus groups with 22 student participants, and 15 individual student interviews. Findings focus on the developing capabilities of autonomy, hope, voice and identity, as well as on the relationship between specific widening participation activities and the developing capability set. The findings highlight the development of college-focused knowledge and how this impacts upon students' aspiration to participate in higher education. The idea of 'widening capability' is discussed in relation to the potential of the capability approach to contribute an additional dimension to a mainly neoliberal policy rhetoric, which emphasises the market value of higher-education participation. In doing so, it explores how widening participation activities can influence the widening capability set of low SES students, and its relationship with what the students deem to be 'a life of value'.
\end{abstract}

Keywords: capabilities approach; widening participation

\section{Introduction}

The capability approach is a theoretical framework that entails two core claims: first, that the freedom to achieve well-being is of primary moral importance and second, that this freedom is to be understood in terms of people's capabilities. It has precipitated an interdisciplinary literature in the social sciences resulting in a new policy paradigm which is mainly used in development studies: the 'human development approach' (Robeyns, 2016). A person's capability represents their freedom or real opportunity set (Commin et al., 2008). In recent times, the capability approach has been used to explore policy and practice in education, and is considered an alternative

^Corresponding author. Trinity Access Programmes, Trinity College Dublin, The University of Dublin, Dublin 2, Ireland. E-mail: osullk14@tcd.ie. Twitter: @osullik7 
to neoliberal perspectives, providing a framework through which the process, purpose and impact of education can be evaluated (Walker, 2006, 2007, 2008, 2012; Unterhalter et al., 2007; Hart, 2013).

In this paper, we present the capability approach as a useful theoretical framework to explore widening participation in higher education for low socio-economic status (SES) students. In so doing, we build on the work of Walker (2008), Tikly and Barrett (2011) and Hart (2013), who examine whether the capability approach can challenge the hegemony of neoliberal discourse in access to higher education. As Walker (2012) suggests, developing widening access to higher education as primarily useful in building human capital is a persuasive and verifiable, market-aligned model, but it offers an impoverished model for education as it does not prioritise well-being, human agency or the transformative potential of education. Chiappero-Martinetti and Sabadash (2010) propose that the capability approach can be complementary theoretically and empirically to policy rhetoric that focuses on widening participation as a vehicle for increasing human capital, as it can offer the prospect that we move beyond 'estimating the market determinants and gains from education to something which more comprehensively embraces plural dimensions of people's lives to better understand the role education plays' (Walker, 2012, p. 387).

Drawing on this work, we propose that the capability approach can provide a broader framework through which to understand the development of low SES students' educational aspirations. The paper begins by setting out the impact that neoliberal discourse has had on the development of widening participation policy and practice. It proceeds to discuss the social and cultural capital limits faced by low SES students and the potential of the capability approach as a framework through which it is possible to consider the educational development of young people towards 'valued beings and doings' (Sen, 1992). It then presents a case study from Ireland which uses the capability approach to research the impact of a university-led widening participation initiative, Trinity Access 21-College for Every Student (TA21-CFES), on the evolution of student knowledge and aspirations. The TA21-CFES project provides students with opportunities to participate in widening participation activities, which aim to build social and cultural capital that specifically relate to future higher-education progression. The paper discusses the impact of these activities on the capability set of low SES students and their developing aspirations.

\section{Educational access and the policy landscape}

Although higher-education participation rates have increased significantly over the last few decades, there is a persistent pattern of inequality of access by low SES students. In Australia, the UK, and the USA, for example, high SES students are three times more likely to enter a high-status university than low SES students. Across selective institutions in the UK and the USA, low SES students account for just 1 in 20 enrolments (Jerrim, 2013).

In Ireland, Power, Flynn, Courtois and Kennedy (2013) and O'Connor (2014) suggest that targets for addressing educational disadvantage and improving highereducation access are rarely met because the policy discourse, which focuses on liberal conceptions of equality, clashes with the increased marketisation of education. 
In the UK, widening participation is also hostage to this discourse through, as Archer, Hutchings and Ross (2003) say, the appropriation of concepts like choice, aspiration and diversity and their subsequent embedding into New Labour education policy.

In Ireland, higher-education participation has increased from $20 \%$ of young adults (aged 17-21) in the 1980s to 52\%, and their progression rate through higher education averages $85 \%$ (Higher Education Authority, 2015), whereas low SES students realised participation rates ${ }^{1}$ of only $14 \%$ in 2013 , against national targets of $31 \%$ (Higher Education Authority, 2015). Research has identified a number of barriers to the educational progression of low SES students, including underperformance at primary and second level (Chowdry et al., 2013; Smyth et al., 2015; Keane, 2015), long-term processes of educational (dis)engagement, problems with school organisation and process (Smyth \& Banks, 2012), impoverished availability of information and guidance (McCoy et al., 2014), the structure of the admissions process and the high-stakes nature of the terminal exam (Higher Education Authority, 2010, 2015; Keane, 2011).

These explanations relate specifically to the quality, content and structure of the education system. Other explanations focus on the familial experiences of the students, and the indirect effects that social, cultural and economic disadvantage (St John et al., 2011; Torgerson et al., 2014) have on educational progression and choice. Bourdieu's (1984) paradigm of cultural reproduction, the dominant explanation for inequalities in social mobility (Donnelly \& Evans, 2016), highlights habitus and cultural capital as central to these barriers. Habitus is 'the practical mastery which people possess of their situations' and cultural capital is the skills, tastes, material belongings and credentials acquired through being part of a particular social class. According to Bourdieu, each class has a different habitus, which informs their values, practices and beliefs. He argues that we have 'internalised, "embodied" social structures... [which] function below the level of consciousness' (Bourdieu, 1986), and impose limits on what we feel we can and cannot do. Bourdieu and Passeron (1977) argue that 'the educational norms of those social classes capable of imposing the criteria of evaluation which are the most favorable to their children' (p. 495) are the ones that prevail and work to exclude the minority classes from participating in higher education. Therefore, cultural capital reinforces social inequalities by valuing the cultural capital of the dominant social classes over the lower SES groups.

Research has shown that when students lack access to forms of social and cultural capital that are valued by the dominant social classes, then educational outcomes are limited (Reay et al., 2005, 2009, 2010; HEFCE, 2015). This focus on social and cultural capital 'deficits' of low SES students has informed the development of widening participation practice, as activities can focus on building their social and cultural capital to facilitate effective 'transition' to the habitus of the dominant culture. Fox (2016) contends that framing interventions in this way implies a lack of legitimacy and recognition accorded to those social and cultural assets of low SES students. Therefore, while widening participation programmes may aim to build social and cultural capital to improve higher-education progression, the deficit discourse can place the locus of responsibility for progression with the individual, neglecting to acknowledge the role of structure in reproducing social inequalities. 


\section{The capability approach, capital theories and widening participation}

The capability approach provides an alternative framework to this deficit model of widening participation under which individual educational progress can be considered. Developed by Amartya Sen (1992) and subsequently elaborated by Martha Nussbaum (2005), the central idea of the capability approach is that social arrangements should aim to expand people's capabilities, which is their freedom to promote or achieve functionings that are important to them. According to Sen (1999), there is greater equality in society when there is parity in people's capabilities to do or be what is valuable to them. A key concept in the approach is people's functioning, which is an achievement or outcome, whereas a capability is the ability to achieve (potential) (Sen, 1985; Walker \& Unterhalter, 2007; Wilson-Strydom, 2012). Therefore, a functioning can be considered the active realisation of capabilities (Nussbaum, 2011). In widening participation practice, this would reconfigure the focus from an outcomedriven approach, based on academic attainment and progression within the existing system, toward an empowering and critical engagement by each student in how future educational options relate to what they value and what they have come to believe they can choose to be or to do. By exploring the capability set that low SES young adults need in order to progress to post-secondary education from a human development perspective, it allows us to explore more humanly rich goals for development through education (Walker, 2012). In this context, 'educational capabilities' refer to low SES students being empowered and informed to choose an educational path that they value.

A capability approach to widening participation refocuses our evaluation of equality from outcome to opportunity by foregrounding the student's capability to be educated. Watts (2012) highlights the importance of this repositioning; he states that Bourdieusian analyses normally engage with the application and acceptance rates to higher education and emphasise the scale of cultural capital required of students to progress, whereas the capabilities approach allows for the possibility that the freedom to make choices includes the freedom to reject what is viewed as the higher or better option, measured by greater potential for individual economic productivity. Thus, the capabilities approach allows us to understand the interaction between students' existing capital and the capital being provided by widening participation activities; it allows an understanding of the development of individual freedom.

Watts (2012) acknowledges that students from low SES communities are often bounded by the limitations imparted by their social, academic and cultural capital, which means that even students who qualify for entry into higher education may adapt their preferences, based on their environment, so that they do not consider certain higher-education institutions as within their reach (Watts, 2012). The capabilities approach offers a lens through which we can begin to understand the complexities of student choice; it provides a framework to consider how students' habitus shifts through involvement in widening participation activities, to broaden their capability set. It offers a broad understanding of how developing capabilities and preferences change over the course of the students' experience with widening participation activities. 
The literature on the capability approach in education has expanded significantly in recent years. In combination with theories of social and cultural reproduction, education researchers have operationalised the capability approach as a useful framework for understanding the complexities of 'meaningful' access to university, and argued that it should be used to consider how education impacts on human development (Unterhalter, 2003; Walker, 2006; Biggeri, 2007; Walker \& Unterhalter, 2007; Wilson-Strydom, 2012, 2015, 2016). Watts and Bridges (2006) contend that for some young people, the challenge of pursuing higher education lies both in the financial implications and in the lack of available social and cultural capital within their community; they assert that the capability approach provides an alternative lens through which to consider long-standing theories of social and cultural capital formation.

Ball, Maguire and Macrae's (2000) study of young people's further education choices in London found that students were not always operating as individual rational calculators' (p. 18), as a human capital approach to education would contend. In this context, a low SES student with the same academic attainment outcomes in second-level education as a high SES student might be expected to have similar opportunities and outcomes in higher education. However, students with apparently equivalent academic outcomes from different SES groups do not have equal employment opportunities, when the social and cultural capital advantages of networks, family history and private schooling are taken into account (Walker, 2012, p. 385). As Share and Carroll (2013) illustrate, low SES students differ in their freedom to convert capabilities into functionings by virtue of other demands on their time, issues with identity and social integration, and adjusting to a dominant higher-education culture. Therefore, while a focus on building social and cultural capital in widening participation programmes could appear to redress social injustices, it may in practice mask the inequalities in opportunity for low SES students to convert capabilities into functionings.

The current research proposes that an explicit consideration of widening participation from a capability approach allows for consideration of these differences in opportunity to convert capabilities into functionings. For example, a student in one of the TA21 project schools who is expected to progress to higher education may be given the opportunity for campus visits and summer schools at later stages in the school cycle (age $16+$ ). She may have a strong academic track record and ambitions to progress. However, she may not have support at home and may be working to contribute to the domestic economy, thereby potentially compromising her attainment. While her ambition has been nurtured by the widening participation programmes and her attainment is strong, she will be less likely to convert her capabilities into functionings in a higher-education setting because of the demands on her time at home. This student may adapt her preferences to a choice that will enable her to do both, to stay close to home and contribute, as well as further her education, despite her ability and the promise of future earnings potential.

In order to understand the complexities of how students adapt their preferences and develop their perception of what is valuable, education researchers have operationalised the capability approach and developed lists of capabilities that are considered important within education. These include human agency and autonomy, hope and voice, identity and knowledge. According to Walker (2008), providing a student 
with agency, including the freedom to decide and 'the power to act and be effective' (Crocker \& Robeyns, 2009, p. 75; Wilson-Strydom, 2012, 2016), is essential for education progression. Similarly, Robeyns (2003) states that autonomy is important in education as it relates to the student's capacity to make informed choices, including decisions regarding planning a life after school, having space for reflection, independence and empowerment. Wilson-Strydom explores this in detail and suggests that the distinction between being able to act and being effective is particularly important in the context of education, as it functions to build skills and capacity.

Building the capability of hope is also considered central to planning a life of value (Walker, 2006). As a capability, hope is closely connected to the capability of voice, because of its importance in addressing adapted preferences and students' capacity to see their future in light of their current situations and structural limitations (Walker, 2006). According to Appadurai (2004), hope offers a perspective on future possibilities not linked to income level; it is the opposite of a sense of entrapment and poverty. Providing students with the capabilities of voice and hope for a different future can be a basis for the development of aspiration insofar as it becomes the basis of a 'thick' aspirational map, which is a flexible horizon of aspirations, rather than a 'thin' aspirational map, which is a less robust sense of what is possible for their future (Appadurai, 2004).

Drawing on Biggeri's (2007) work on capabilities and on Freire's (1973) and Thomson's (1999) work on learner identity formation, the capability of identity is also considered central to students' ability to imagine and work towards a future in higher education. Irish educational policy documents recognise identity as being central to the continuing process of value formation in students (Higher Education Authority, 2015) and for low SES students, the ability to participate in higher education requires a shift in self-concept and an ability to see education and work possibilities in one's future that do not exist in one's own immediate context (Biggeri, 2007).

Knowledge is considered an important capability in terms of educational change. Robeyns (2003) contends that knowledge is fundamental to educational uplift; she describes the importance of students developing knowledge of school subjects which are either intrinsically interesting or instrumentally useful for post-school choices of study, paid work and a career. Having knowledge of others with whom they can identify, and knowledge for critical thinking and active inquiry, are considered an important capability that should be developed through education. According to Appadurai (2004), knowledge gained at school may be intrinsically valued, instrumentally valued (work) or positionally valued (a better university, expanded career options); having this knowledge and the credentials that would not be possible without it expands opportunities, agency and freedom and again, can contribute to a 'thick' aspirational map (Appadurai, 2004, p. 186).

\section{The current study}

The current study examines the usefulness of the capabilities approach in understanding the development of low SES student aspirations. We take the perspective that the aspiration to progress on to higher education would be influenced by the developing capabilities of agency, hope and voice, identity and knowledge; and that 
activities which aim to provide students with access to specific forms of capital could be framed under a broader human development framework. We propose a 'widening capability' (Walker, 2008) approach, which aims to shift the widening participation policy narrative from a focus on student progression to student potential and capability. We will explore how low SES students' existing capability and capital set interacts with widening participation experiences to influence students' views on what constitutes 'a life of value' and how they define and develop aspirations.

\section{Method}

This research uses a case study approach to examine the developing capability set of Irish students from a representative sample of four schools participating in the TA21CFES programme. A qualitative approach was adopted and the data discussed are illuminative rather than generalisable, as they are taken from a small sample of students. At the end of the first year of the three-year TA21-CFES programme, 22 students participated in focus groups and 15 students participated in interviews. All students were in their second year of secondary school and aged 14 . Permission to interview the students was sought from guardians as well as from student participants. Interviews were conducted individually with each student and we were mindful throughout of the sensitive ethical dimensions of the study. In order to depersonalise the content of the interview, and initiate conversation, we used photographs that depicted school, family, work and future to ask about why others would deem these thematic areas important for their future. A description of the students and the four schools is provided in Table 1 .

All students had participated in the first year of the structured TA21-CFES project, which included three 'core practices'. The TA21-CFES core practices were developed based on a revision of the existing widening participation literature and the experience of two large-scale widening participation projects running in the USA and Ireland. Some activities were adapted from the US not-for-profit project College for Every Student - a programme which offers schools support in implementing activities relating to social and cultural capital development - and some were developed from the Trinity Access Programmes, which has run outreach work in low SES secondary schools for over 20 years. TA21-CFES was aimed specifically at students from schools and communities where higher-education participation was historically low; its primary aim was to encourage participation in higher education across Ireland, rather than being specific to the institution in which the programme was running. The core practices were: (1) mentoring via six structured sessions with a university undergraduate or graduate who was also from a low SES background; (2) pathways to college activities, including a visit to a higher-education campus and information sessions on higher-education progression and related careers; and (3) participation in Leadership through Service, a student-led service project which positively impacted upon the students' school or community. These core practices were modelled on the College for Every Student model. They were adapted to the Irish context and developed to align with research which has focused on the social and cultural capital constructs identified as supporting educational uplift in low SES students (St John et al., 2011). The constructs included building trusting relationships, developing networks 
Table 1. School and participant details for interviews and focus groups

\begin{tabular}{|c|c|c|c|c|}
\hline & School 3 & School 5 & School 9 & School 10 \\
\hline \multirow[t]{12}{*}{ Interviews } & Bobby & Ellana & Dale & $\mathrm{Aja}$ \\
\hline & Female & Female & Male & Female \\
\hline & Irish & Irish & Irish & Polish \\
\hline & John & Alene & Calan & Ash \\
\hline & Male & Female & Male & Female \\
\hline & Irish & Irish & Dutch & African \\
\hline & Ollie & Kaylee & Luigi & Geo \\
\hline & Female & Female & Male & Female \\
\hline & Irish & Polish & Irish & Irish \\
\hline & & Cal & Kelly & Mike \\
\hline & & Female & Female & Male \\
\hline & & Irish & Asian & Irish \\
\hline \multirow[t]{18}{*}{ Focus groups } & Terry & Keilty & Vlad & Elly \\
\hline & Male & Female & Male & Male \\
\hline & Irish & Irish & Polish & Romanian \\
\hline & Kyle & Amma & Sophie & Caly \\
\hline & Male & Female & Female & Female \\
\hline & Irish & Irish & Irish & Irish \\
\hline & $\mathrm{Nic}$ & Fran & Dee & Bill \\
\hline & Female & Female & Male & Male \\
\hline & Polish & Irish & African & Irish \\
\hline & Daryl & Zarah & Tania & Ollie \\
\hline & Male & Female & Female & Female \\
\hline & Irish & Hungarian/Romanian & Irish & Irish \\
\hline & Cillian & Caley & & \\
\hline & Male & Female & & \\
\hline & Irish & Irish & & \\
\hline & & Sonya & & \\
\hline & & Female & & \\
\hline & & Irish & & \\
\hline
\end{tabular}

Table 2. Alignment of social and cultural capital formation, TA21-CFES core practices and activities

\begin{tabular}{llc}
\hline Practice & \multicolumn{1}{c}{ Activities } & Capital \\
\hline $\begin{array}{l}\text { Pathways to } \\
\text { college }\end{array}$ & $\begin{array}{l}\text { 1. Minimum of one university campus visit per year } \\
\text { 2. College course investigations } \\
\text { 3. Parent discussion on college course investigation } \\
\text { 4. College student visit school }\end{array}$ & $\begin{array}{c}\text { Cultural and } \\
\text { social capital }\end{array}$ \\
Mentoring & $\begin{array}{l}\text { 1. Minimum of six college-focused mentoring sessions with } \\
\text { low SES college student/graduate }\end{array}$ & $\begin{array}{c}\text { Social and } \\
\text { cultural capital }\end{array}$ \\
$\begin{array}{c}\text { Leadership } \\
\text { through Service }\end{array}$ & 1. Students lead a service activity & Cultural capital \\
\hline
\end{tabular}


through which college-related information can be transferred, and the development of college and career-related knowledge and skills. Table 2 describes how the TA21-CFES activities align with the processes related to social and cultural capital development.

The formulation of the themes and subthemes in the interview and focus group schedules was guided by the work of St John et al. (2011) and by the capabilities discussed in the Introduction; these included autonomy, hope and voice, identity and knowledge. The list of capital-formation processes listed in Table 2 was employed to generate interview schedules, and later used to code the interview and focus group data. We also used the capabilities as an additional guide to coding the data.

\section{Qualitative analysis}

The following section describes the capabilities that were identified through the thematic analysis and the relationship between these capabilities and the core practices that students experienced through the TA21-CFES project (Leadership through Service, pathways to college and mentoring). Autonomy, hope and voice, and identity are the main capabilities emerging as a result of participation in the activities aimed at increasing the capital constructs of the students. These are discussed in order of their impact, with autonomy being the most influential capability while identity has a smaller impact. Finally, we present evidence that knowledge, as both a capability and a capital process, impacts upon how students see themselves in relation to higher-education progression, and how the practices of the TA21-CFES project provide qualitatively different forms of knowledge which support aspiration development and freedom of choice in the students.

\section{Autonomy}

In the analysis we observe that participation in activities which aim to develop cultural and social capital constructs such as information, networks and trust impact upon a stronger sense of autonomy in low SES students.

Throughout the interviews and focus groups, there was strong evidence that the Leadership through Service project, which allows students to lead a service-based project, was fundamental to a shift in their sense of autonomy and self-perception. It provided students with the opportunity to develop new skills and to overcome barriers. Students designed 'Leadership through Service' projects which would positively impact upon their community, giving them space and time to plan, lead and follow through on their initiative. Students in all four schools discussed how leading and developing the projects helped them feel empowered and more able to 'take control of what you're doing'. Sonya, a girl from School 5, said that the leadership project helped the students in her school develop a sense of purpose and responsibility, reflecting that it has made them think more seriously:

\footnotetext{
... we're more serious [because of the leadership project] ... because we now know how much work had to go into it to make it a thing. Like, we had to get permission off teachers, we had to get furniture, and we had to get everything sorted out. We had to paint a room; we had to choose what colours to use.
} 
By empowering the students to lead a service-focused activity, the TA21-CFES project is enhancing students' sense of responsibility and pride in their work; seeing a project through from start to finish was important to their sense of accomplishment. School 5 completed a substantial project, where they redesigned a classroom, turning it into a twenty-first-century project room for more active teaching and learning methodologies. The students in this school scoped the entire project, secured financial support for its development and worked collaboratively to effectively complete the project room. Students in this school demonstrated surprise in their own capacity to achieve their goals; they were proud to have seen the project to completion and of their growing confidence in working together effectively as a team:

It was almost a sense of pride really because you thought up a project and you had an idea and it was only a rough idea and then just to see it all carried out and actually say, we completed this, do you know what I mean, I think it's like almost like, I know we're in second year and it's just, it feels like it's something big to us.

The students in School 5 said that the experience was helpful in developing their sense of autonomy and confidence, as they presented the project to new external networks and to people who had been to higher education. This pride in their autonomy and a recognition of enhanced confidence was consistently seen in all schools. Bobby in School 5 illustrates this in her observation:

we had to research on this and we had to present it so it really helped be confident that time, and I was not really confident and you know you had to meet other people, students, and it wasn't really good at the first meeting but the second time it was okay cause you were comfortable...

The leadership project's impact on student autonomy was evident in a comment made by John in School 3:

It wasn't the teachers doing it, it was us so it was showing us like that actually there is organising that goes into stuff. .. they gave us a great experience of leading a team and seeing all what you have to do to be a good leader and stuff.

Many students referred to the sense of accomplishment they had experienced by leading without the teachers. In School 9, Calan and Dale both talk about how this gave them a sense of 'I can', with Dale highlighting the sense of responsibility they all felt: 'there was no teacher behind you to say what you had to mention, it was all just us so we had to make sure that we included everything'.

Completing the leadership project has given them a sense of pride-'we can stand proud of what we did'. It has underscored the importance of organisation and planning in their habitual patterns, in order to get to where they intend to go. Zoe in School 9 reflects on this point, when talking about the importance of the leadership project:

... Cause like if you're not organised, if you don't organise your locker then you're probably going to be late for class. You're going to be in constant trouble. So like you have to be organised.

Throughout the interviews there was evidence that students were more hopeful because of the knowledge they were gaining at an early stage in their second-level education about future options: 
I want to go to college but I was always really afraid of college. I'll always think college is this big thing that I probably wouldn't be getting into, and now I see it's not just because of who you are that you can't get into it. Like if you work hard enough you will get into somewhere.

There are consistent references to the TA21-CFES programme teaching them that 'working hard' and being responsible will support their progression to college. There is less evidence at this stage, however, that they acknowledge other limitations which may affect their educational progression, such as academic attainment or family and community influences.

Students have built social capital through their mentoring relationships, which has provided them with trustworthy information and broader networks of relatable role models. Most of the mentors were recruited from low SES students and alumni who had progressed to Trinity College Dublin via the access programmes, so they were deemed 'relatable'. Some mentors were drawn from the secondary school itself, and were students who were in their final year of school and who had college aspirations. The students talk about how these relationships have shown them that they have the freedom to choose what they want to be or do and how having this perspective supported, particularly through mentoring, has helped them to believe their future plans are more attainable. Keilty in School 5 talked about the importance of having someone reassuring in her life, who knew how to navigate the education system. She said of the mentors:

They're just more like reassuring... [They] make sure that you can do that course. Just like, you know that you can get there if you wanted.

Calan in School 9 talked about the importance of mentoring, and how it provided him with the sense that he can achieve:

Interviewer: What effect has mentoring had on you?

Calan: Like it has opened our eyes to say 'well they've achieved it'.

Interviewer: And what does that make you feel?

Calan: That if they can do it then we can do it.

This exchange, an example of many others, demonstrates the importance of the mentoring relationship in transferring information that supports the development of autonomy in the students. This autonomy was particularly related to the sense that they can achieve their goals and there is evidence that they are converting this enhanced autonomy into functionings, such as completing school work to a high standard, focusing on their longer-term goals and improving their academic attainment.

\section{Hope and voice}

The evidence emerging from the TA21-CFES project is that hope is developing in the students through expanded, trusted networks, greater knowledge about college and careers and an awareness of how to persist through barriers. These have been facilitated by pathways to college and mentoring practices. 
There is an abundance of evidence that the TA21-CFES project is providing students with hope for their future. Ellana said 'the activities made us more inspired, to go to college like they made us [want to] stay in school, and em, reach our goals'. Students are clearer on their own role in achieving these goals and demonstrate an understanding of overcoming barriers to make their aspirations attainable. Bobby in School 3 talks about visiting a higher-education campus and how the information, and exposure to the institution, has affected her sense of hope:

It makes your dream reality... Like you can always think about 'Oh yeah, I'll get my... third level education' but actually going to $\mathrm{X}$ college, seeing real students, real people, talking to real lecturers, it makes it [a] reality. It's possible to go to college.

The knowledge they have built through the project has developed their cultural capital and given them greater hope that they can get to higher education. Students demonstrate an understanding that there are alternative routes into higher education and this reduces pressure around academic attainment required in the final, second-level school examinations. They are using this knowledge to develop new habitual patterns such as focused work, setting clear attainment goals for themselves, taking more 'higher'-level subjects and staying away from social events with peers to ensure they complete the tasks they have set for themselves. Students now realise that higher education will be more likely to deliver a job that 'you want to get up every morning and go to...' They associate not going to college with a lack of hope and imagine a life 'living off and drinking alcohol everyday...' where if 'you had no job you'll be living on scraps'. In School 5, students in the focus group talk about the importance of resilience and reflect on their own family experience and the lack of choice evident for those in their community with low educational attainment. This, alongside the new information from the TA21-CFES programme, is helping them to scaffold a different set of aspirations for themselves:

Keilty: Yeah! It really does because before it, I wanted to go to college but I wasn't really sure if I could because of finances. Like cause like I come from a background where money is kinda tight and not, not most of my family have got a degree or masters from college.

Amma: Em like my mum didn't go college so I don't want to be like her like she doesn't have a job an all. So if I go college maybe I'll get a job.

Keilty: Emm I dunno it's just like me da does buildings. I don't think he actually likes it cause he always like, he comes home tired but ye you'd be tired after workin, but I think he just does it so he can like, help us with the money in the house and like, like with the food and all.

There are, however, cases where students are still uncertain about the future and there is some evidence that informing students of the pathways to college can reduce their hope. Cal in School 5 talked about how she was unsure about her chances of realising her aspirations:

I don't know if in the future I'm going to be able to do what I want to do. . . like the job and everything and all this... in college, if you go to college and if you get the things that you 
need you should get what you want. . . like your goals achieved... but if that doesn't happen then [you] obviously can't reach them.

What is important about this observation is that students are being encouraged to examine their options and interests in relation to higher education, and while some were inspired and hopeful through these activities, others were not. While the TA21CFES programme encourages all students to consider some form of post-secondary education, it is essentially to support students to make informed choices about their future, whatever those choices may be. This reflects Watts's (2012) observation that a capability approach to widening participation foregrounds freedom of choice, including the freedom to reject what is considered the better option, measured by greater potential for individual economic productivity.

Other students were modifying their aspirations, based on a more realistic appraisal of what they were likely to achieve. This is evidenced by the conversation in a focus group in School 10:

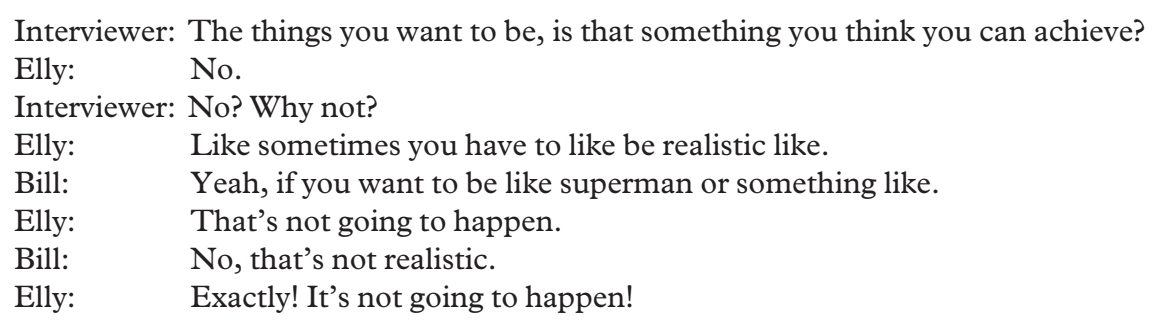

Students were experiencing a conflict between their hopes for the future, their own self-concept and the information they were receiving in their families and in school. As Fox (2016) and Watts (2012) illustrated, the students are struggling to identify the value of their own social and cultural capital in an educational landscape that frames academic attainment and post-secondary progression as the legitimised and recognised forms of 'success'. Mike in School 10 talked about different types of 'smartness' and how despite not having 'school smartness', he can still amount to something. He is trying to realign his own self-concept with the new knowledge he has developed through the programme, and reassure himself regarding his future. Eric also remarked on this and gave examples of smart people who were 'successful' but had not progressed to higher education:

and there's some people that haven't gone college that turned out to have great inventions so I'd kinda just follow that route like if I can't go to college I wouldn't just jump at a low paid minimum wage job, I'd kinda just try do something better and kinda think 'If I didn't go college, I still have hope'.

Bill talked about how his brother didn't go to college, but:

My oldest brother, he works in the airport and I think that's a bit good for him, cause he's getting money to pay rent and to try get a new house and all. And then my other brother, he has a like good enough job for himself. 
Students were defending the choices of their family and it was clear there was some level of discord between the information being gained through TA21-CFES and the family experience. This is seen in the following exchange:

Student: But isn't there other jobs that you don't need college for? If that makes sense, like you can, can't you work in certain offices if you're like... is that... right or wrong?

Interviewer: What kind of offices?

Student: Like, see if you finish your Leaving Cert, and you had got good points in your Leaving Cert but you didn't go to college, and you went to get a job. Would they not check your Leaving Cert?

The discord between what the project was telling students about higher education and their own experiences in their families was offset by some through the relationship with their mentor. Almost all students refer to the importance of 'relatable' mentors in developing hope about progression to higher education. Kelly in School 9 talked about the importance of learning about her mentor's past:

You see how some people started from a different background. And how like they kinda worked hard to get to where they are. So like, kinda makes it - you can do it if you try.

Students commented on how wider college networks, developed through the mentoring and pathways to college core practices, had made them more hopeful about their future. Some describe their mentors as 'someone to look up to', or 'someone you can ask questions to if you're not sure about college and stuff', which is 'really helpful', especially when they come from families where there are 'no people with masters or degrees'.

\section{Identity}

Students were conflicted about whether they would 'fit in' to higher education. They spoke about those 'types of people' and how 'doctors and lawyers' go to college. Even after one year of TA21-CFES, some students were still reluctant to see themselves as belonging within universities that they deem 'higher-class'. For example, Cal in School 5 said she would rather apply to a less selective university, as one specific university is not for people like her. Even with experience of college campuses and developing networks, students' self-concept did not fully align with that of a college-going student and they were uncertain as to whether they would belong in certain careers. In School 5 this was particularly evident, with the students talking about college usually being for 'people with money' and students in School 10 emphasising college being for 'smart people'. There was also reference to the different types of institutions, and how they would not be able to 'fit in' to the more selective universities.

Even though the programme had provided students with meaningful opportunities to meet with students in higher education from their community, there was no sign that they felt that their 'difference' within some institutions might be an asset within the teaching, learning and cultural context, or that the institutions might adapt to better represent a more diverse cohort (Trinity Access Programmes, 2010; Share \& Carroll, 2013). Neither did they demonstrate an understanding that there may be 
ongoing identity issues in their experience of higher education. Yet, as Share and Carroll (2013) illustrate, first-generation university students can compartmentalise their lives due to a continuing sense of conflicted identity between community and college. They experience difference and isolation that they may be unable to discuss with their family or friends (London, 1989). Moreover, as London (1989) remarks, 'first generation students can carry the baggage of intergenerational family dynamics that impacts on their sense of belonging and causes confusion about role assignment in their families'. This can elicit 'survivor guilt' (Wray, 2009) when they consider the opportunities they have had in comparison with other family members.

Not all students were conflicted about their higher-education aspirations. Students who had long-standing aspirations to progress to higher education spoke about how the project had changed their aspirations to more concrete objectives. They can see themselves, and their future identity, as one that includes attending a 'good' highereducation institution. For instance, Mike in School 10 demonstrated a real sense of excitement about his future potential, which he developed in part through a relatable role model. Describing his mentor, he said:

He likes physics and I like physics and he was kind of saying why he chose it and like, he was saying all the things he can do and like the freedom you kinda have...

The connection he made with his mentor about subject interest was key to him visualising his future self in higher education.

\section{Knowledge}

In the current study the development of different forms of knowledge emerged as a significant factor in developing student aspiration. Knowledge was defined here as system knowledge rather than skills or academic abilities. The students said that the information gleaned through TA21-CFES was providing students with a 'road map' to college. One student stated that TA21-CFES was 'a guide to know what to do for college'; a point that was reiterated by students across several schools. The types of information gained varied and seemed to have differing effects on students' perceptions. There was factual information and experiential information; the factual information related to information about entry requirements, subject choices and points requirements. Factual information seemed to be reducing students' fears and opening up a world previously relatively unknown to them:

Bobby: It kind of made us less scared than we used to be about going to college. . . 'cause now you know it's only going to be a few forms.

Cal: I didn't really know what college was. I thought you just picked a random college and got a job... Like I didn't know you had to plan and the points for college.

The mentors provided experiential information to the students, and the students referred to the importance of having mentors who come from similar communities as them, saying that this provides a strong foundation from which new, trusted information can be assimilated. Relationships with their mentors helped students develop different attitudes towards college. A theme that was reiterated by many was 'if they can do it, then so can I'. The information provided by mentors also allowed students to 
develop an understanding of alternative entry routes to college. Alene talked about how her mentor showed her the different paths to higher education:

I heard [from my mentor] that if you get lower than you're aiming... you can take [an access] course... and then you go through that course and then you do some examinations in that and then if you do well you can go on to your [degree] course if you want to... It's more years to do your course, like four years for your course, but it might take six because you needed two years to get into your course.

The combination of the factual and experiential knowledge provided by the overall project is developing students' perception of higher education, even in those who resisted the idea of college:

[Last year] we had a negative thing about college like it was so bad and all but that just wasn't true, but after seeing what it's like, it's much better.

I never really wanted to go to college but it's making me, because we went to colleges and all; it's making me want to go to it; just it's making me want to go to it now.

The information has also helped students become clearer about their future plans, even if that meant they had decided that university was not for them. When asked if TA21-CFES changed their plans for the future, one student replied 'No... I still want to become a mechanic'.

Other students reported being more informed about where they could go and what they could study. Some realised that they were restricted to certain places (' $I$ decided there was only one college I could go to if I wanted to be a vet and that was UCD'), while others were encouraged by the range of choice available to them:

I wanted to be a music teacher but there's other things I could've done. I could've done music technology or music for commercials and all that, like there's a lot, you find out there is more of a range of courses that you can take on, instead of just teaching. (Kelly)

\section{Discussion and conclusion}

In this paper, we present evidence that students who participate in an initiative aimed at providing access to specific forms of cultural and social capital are developing the capabilities identified as important to navigate higher education. We provide evidence that students are developing a sense of autonomy in their ability to make choices, alongside hope and voice regarding future career options. Students are using information to refine how they express these options and how they relate them to their identity. Through the opportunities provided by higher-education mentors and on-campus experiences, the students' knowledge has grown and they are expressing clearer educational aspirations.

We demonstrate that students who have the opportunity to develop higher-education-related social and cultural capital can develop a capability set identified in the literature as critical to post-secondary educational progression. We present this perspective as a counter-narrative to neoliberal discourse in access to higher education, which focuses primarily on volume, attainment and skills gaps rather than on student choice. 
The evidence presented supports the views of Walker (2008), Crocker and Robeyns (2009) and Wilson-Strydom $(2012,2016)$; they state that providing a student with agency, including the freedom to decide and 'the power to act and be effective', can support the capability to aspire. The students in this case study have the scope to develop autonomy through leadership roles, new mentor relationships and exploration of college courses and campuses. This is enhancing their ability to make informed choices, as autonomous agents, about whether or not they wish to aim for higher education. Using the capability approach as the basis for understanding student choice and aspiration moves the needle from outcome-focused metrics to providing students with practical contexts in which they can develop agency to support their own educational decisions.

The students in this case study report a growing sense of hope which, as Walker (2006) says, is central to planning a life of value and, as Appadurai (2004) observes, offers a perspective on future possibilities not linked to income level or current social structures. Through the mentoring relationship and exposure to college norms, the capability of voice and hope for a different future is developing; this hope is the basis for the development of aspiration insofar as it provides students with a stronger sense of future possibilities. This growth in aspiration is further supported by the knowledge students are developing; according to Robeyns (2003), having system knowledge acquired with relatable others for active inquiry represents an important capability that should be developed through education. The students in this case study demonstrate developing knowledge of college structures, entry requirements and how to navigate the system. The current research proposes that this type of knowledge is considered a capability as it supports student aspirations. As Robeyns (2003) states, such knowledge is fundamental to educational uplift as it is instrumentally useful for postschool choices of study, paid work and a career.

Appadurai (2004) contends that providing students with the capabilities of voice and hope for a different future can be a basis for the development of a 'thick' aspirational map, which has flexible horizons about their future, rather than a 'thin' map which has a smaller number of nodes and a weaker sense of what is possible for the future (Appadurai, 2004). Our research speaks to this assertion, as participation in capital-forming activities which support the development of autonomy, hope and voice, and knowledge, are supporting what could be considered a 'thick' aspirational map in the students. When they demonstrate knowledge of different routes of entry (nodes), knowledge of different college courses and trust in their mentor's message, they are demonstrating a thick map, with many nodes through which they can navigate structures.

These findings provide a counter-narrative to the deficit discourse elaborated on by Watts (2012) and Fox (2016), which critiques the appropriation of Bourdieu's theory of cultural reproduction in producing adequate 'capital' for low SES students to adapt to the higher-education habitus. Such an approach to widening participation programmes fails to engage with the structural context within which students develop their capabilities and the differences they encounter in ability to convert these capabilities into functionings. A capability approach, on the other hand, shifts the focus from an outcome-driven approach that considers academic attainment and progression in an existing system, to an empowering and critical engagement with what each student 
values and has reason to value and what additional social and cultural capital they may need to freely make an informed choice and build their aspirational map.

While the aspirations of low SES students were apparently increased through the development of their emerging capability set, it is not yet clear if these capabilities will develop into actual functionings or if they will produce what Berlant (2006) calls 'cruel optimism'; that is, high aspirations but with little realistic possibility of attaining them. It was clear that some students are more invested in higher-education ambitions as a result of participation in the TA21-CFES project and there was a relationship between the development of autonomy, voice, hope, knowledge and these ambitions; what is less clear is whether aspirations will be realised under present conditions. According to Hart (2013), there is a fine line between promoting the capability to aspire in a supportive environment and setting students up for a fall by getting them to dream the unattainable. Yet, as Hart (2013) also observes, aspiration-promotion is a necessary dimension in encouraging young people to formulate and work towards achieving their educational goals. The current findings suggest that interventions aimed at broadening the social and cultural capital of low SES students do impact upon their capability set and students perceive their abilities differently as a result of more autonomy, hope and knowledge.

While the early evidence presented here shows that this school-based initiative, which focuses on specific capital-formation processes, can be linked with the capability approach, there are also challenges which emerge. For some, the new forms of capital raised fears of not belonging, highlighted the differences in their families and challenged their identity. Some students were unsure they would belong in higher education. Students have a stronger sense of autonomy about their future but are less aware of the structural barriers they may face. For instance, they observe that if they work hard they will achieve their educational goals and be well positioned to progress to a career that is of value to them. However, they are less aware that other students with similar academic attainment may have social and cultural capital that supports them in more easily reaching their career goals. Students would be better prepared to develop a 'thick' aspirational set if they were more aware of the likely structural barriers and approaches they might use to mitigate these in their own trajectory. It is critical that widening participation programmes work with students to develop their knowledge and navigational skills to engage with and address structural obstacles, if they are to avoid being providers of Berlant's (2006) 'cruel optimism'.

This research provides evidence of the value of a capability approach to widening participation. It points towards some key areas for future research, such as expanding the examination of the formation of young people's capability set and the relationship between these capabilities and their functionings within higher education. Taken together, these approaches would advance the development of a human development-focused educational policy discourse.

We have argued that we can reclaim widening participation policy and practice from a predominantly neoliberal discourse, which foregrounds the role of higher education in building human capital for greater economic productivity, through synthesising social and cultural capital theories with the capabilities approach. In so doing we build on the recent work of Lanzi (2007), Chiappero-Martinetti and Sabadash (2010), Walker (2012), Wilson-Strydom (2012) and St John (2013), all of whom 
contend that education policy formation would be strengthened by the greater use of human-development theory. This catalyses the development of an alternative discourse, policy and practice on the potential of widening participation, not just to prepare more students to be individuals who generate economic value, but also to play an essential role in providing them with greater freedom to develop a 'life of value'.

\section{NOTE}

1 Participation rates here refers to the percentage of that SES group progressing to higher education.

\section{References}

Appadurai, A. (2004) The capacity to aspire: Culture and the terms of recognition (Stanford, CA, Stanford University Press).

Archer, L., Hutchings, M. \& Ross, A. (2003) Higher education and social class: Issues of exclusion and inclusion (London, Routledge).

Ball, S. J., Maguire, M. \& Macrae, S. (2000) Choice, pathways and transition posts (London, Routledge).

Berlant, L. (2006) Cruel optimism, Differences: A fournal of Feminist Cultural Studies, 17(3), 20-36.

Biggeri, M. (2007) Children's valued capabilities, in: M. Walker \& E. Unterhalter (Eds) Amartya Sen's capability approach and social justice in education (New York, NY, Palgrave Macmillan), 197-214.

Bourdieu, P. (1984) Distinction: A social critique of the judgement of taste (transl. R. Nee) (Cambridge, MA, Harvard University Press).

Bourdieu, P. (1986) The Force of Law: Toward a Sociology of the Legal Field, Hastings LJ, 38, 805.

Bourdieu, P. \& Wacquant, L. (1992) An invitation to reflexive sociology (Cambridge, Polity Press).

Bourdieu, P. \& Passeron, J.-C. (1977) Reproduction in education, society and culture (London, Sage Publications).

Bowes, L., Moreton, R., Thomas, L. \& Porter, A. (2013) Formative evaluation national scholarship programme: Addendum and summary of year 1. Report to HEFCE by CFE and the Widening Participation Research Centre, Edge Hill University (Bristol, HEFCE).

Chiappero-Martinetti, E. \& Sabadash, A. (2010) Human capital and human capabilities: Towards a theoretical integration. Paper prepared for the project 'WorkAble' (Pavia, University of Pavia).

Chowdry, H. et al. (2013) Widening participation in higher education: analysis using linked administrative data, fournal of the Royal Statistical Society: Series A (Statistics in Society), 176(2), 431457.

Coleman, J. S. (1988) Social capital in the creation of human capital, American fournal of Sociology, 94, 95-120.

Commin, F., Qizilbash, M. \& Alkire, S. (2008) The capability approach: Concepts, measures and applications (New York, NY, Cambridge University Press).

Crocker, D. A. \& Robeyns, I. (2009) Capability and agency, in: C. Morris (Ed) Amartya Sen (New York, NY, Cambridge University Press), 60-90.

Freire, P. (1973) Education for critical consciousness (Cambridge, Continuum).

Hart, C. S. (2013) Aspirations, education and social justice: Applying Sen and Bourdieu (London, Bloomsbury).

Higher Education Authority (HEA) (2010) National plan for equity of access to higher education 200813 - mid-term review. (Dublin, Higher Education Authority).

Higher Education Authority (2015) National plan for equity of access to higher education 2015-19 (Dublin, Higher Education Authority). 
Higher Education Funding Council for England (HEFCE). (2015) Delivering opportunities for students and maximising their success: evidence for policy and practice 2015-2020 (Bristol, Higher Education Funding Council for England).

Jerrim, J. (2013) Family background and access to 'high status' universities (London, The Sutton Trust).

Keane, E. (2011) Distancing to self-protect: the perpetuation of inequality in higher education through socio-relational dis/engagement, British fournal of Sociology of Education, 32(3), 449466.

Keane, E. (2015) Considering the 'Impact'of access and widening participation: the undergraduate, postgraduate and employment experiences of NUI Galway access students (Galway, i Access Centre)

Lanzi, D. (2007) Capabilities, human capital and education, Fournal of Socio-Economics, 36(3), 424-435.

London, H. (1989) Breaking away: A study of first-generation college students and their families, American fournal of Education, 97(2), 144-170.

McCoy, S., Smyth, E., Watson, D. \& Darmody, M. (2014) Leaving school in Ireland: A longitudinal study of post-school transitions (Dublin, ESRI).

Nussbaum, M. (2005) Wellbeing, contracts and capabilities, in: L. Manderson (Ed) Rethinking wellbeing: Essays on health, disability and disadvantage (Perth, API Network), 27-44.

Nussbaum, M. (2011) Creating capabilities: The human development approach (Cambridge, MA, Harvard University Press).

O'Connor, M. (2014) Investment in edification: Reflections on Irish education policy since independence, Irish Educational Studies, 33(2), 193-212.

Power, M., O'Flynn, M., Courtois, A. \& Kennedy, M. (2013) Neoliberal capitalism and education in Ireland. Department of Sociology, Working Paper WP2013-03 (Limerick, University of Limerick).

Reay, D., David, M. E. \& Ball, S. J. (2005) Degrees of choice: Class, race, gender and higher education (Stoke-on-Trent, Trentham Books).

Reay, D., Crozier, G. \& Clayton, J. (2009) 'Strangers in paradise'? Working-class students in elite universities, Sociology, 43(6), 1103-1121.

Reay, D., Gill, C. \& John, C. (2010) 'Fitting in' or 'standing out': working-class students in UK higher education, British Educational Research fournal, 36(1), 107-124.

Robeyns, I. (2003) Sen's capability approach and gender inequality: Selecting relevant capabilities, Feminist Economics, 9(2\&3), 61-92.

Robeyns, I. (2016) Capabilitarianism, fournal of Human Development and Capabilities, 17(3), 397414.

Sen, A. (1985) Well-being, agency and freedom: The Dewey lectures 1984, fournal of Philosophy, $82(4), 169-221$.

Sen, A. (1992) Inequality reexamined (Oxford, Oxford University Press).

Sen, A. (1999) Commodities and capabilities (Oxford, Oxford University Press).

Share, M. \& Carroll, C. (2013) Ripples of hope: The family and community impact of Trinity College Dublin access graduates (Dublin, Children's Research Centre).

Smyth, E., McCoy, S. \& Kingston, G. (2015) Learning from the evaluation of DEIS. ESRI Series Report No. 39 (Dublin, ESRI).

Smyth, E. \& Banks, J. (2012) 'There was never really any question of anything else': young people's agency, institutional habitus and the transition to higher education, British fournal of Sociology of Education, 33(2), 263-281.

St John, E. P., Hu, S. \& Fisher, A. S. (2011) Breaking through the access barrier: Academic capital formation informing public policy (New York, NY, Routledge).

St John, E. (2013) Research, Actionable Knowledge E Social Change (Virginia, Stylus).

Trinity Access Programmes (TAP) (2010) Ten years on: the experiences of mature students in tap and trinity (Dublin, TAP).

Thomson, P. (1999) How doing justice got boxed. In: A cautionary curriculum tale for policy activists, in: B. Johnson \& A. Reid (Eds) Contesting the curriculum (Sydney, Social Science Press), 24-33. 
Torgerson, C. et al. (2014) Higher Education access: Evidence of effectiveness of university access strategies and approaches (London, Sutton Trust).

Tikly, L. \& Barrett, A. M. (2011) Social justice, capabilities and the quality of education in low income countries, International fournal of Educational Development, 31(1), 3-14.

Unterhalter, E. (2003) The capabilities approach and gendered education - an examination of South African complexities, Theory and Research in Education, 1(1), 7-22.

Unterhalter, E., Vaughan, R. \& Walker, M. (2007) The capability approach and education, Prospero, 13(3), 13-21.

Walker, M. (2006) Towards a capability-based theory of social justice for education policy-making, fournal of Education Policy, 21(2), 163-185.

Walker, M. (2007) Selecting capabilities for gender equality in education, in: M. Walker \& E. Unterhalter (Eds) Amartya Sen's capability approach and social justice in education (Basingstoke, Palgrave Macmillan), 177-195.

Walker, M. (2008) Widening participation; widening capability, London Review of Education, 6(3), 267-279.

Walker, M. (2012) A capital or capabilities education narrative in a world of staggering inequalities?, International fournal of Educational Development, 32(3), 384-393.

Walker, M. \& Unterhalter, E. (Eds) (2007) Amartya Sen's capability approach and social justice in education (Basingstoke, Palgrave Macmillan).

Watts, M. F. (2012) The ethics of widening participation: The funding of higher education, in: F. Su \& B. McGettrick (Eds) Professional ethics: Education for a humane society (Newcastle-uponTyne, Cambridge Students Publishing), 138-153.

Watts, M. \& Bridges, D. (2006) The value of non-participation in higher education, fournal of Education Policy, 21(3), 267-290.

Wilson-Strydom, M. (2012) A framework for facilitating the transition from school to university in South Africa: A capabilities approach (Bloemfontein, University of the Free State).

Wilson-Strydom, M. (2015) University access and theories of social justice: Contributions of the capabilities approach, Higher Education, 69(1), 143-155.

Wilson-Strydom, M. (2016) A capabilities list for equitable transitions to university: A top-down and bottom-up approach, fournal of Human Development and Capabilities, 17 (2), 145-160.

Wray, J. (2009) Research finds some first generation students experience 'survivor guilt' (Arizona, University of Arizona). 